\title{
Usage of Track Link Dynamic Motion Simulation
}

Chalupa Milan ${ }^{1}$, Veverka Josef ${ }^{2}$, Vlach Radek ${ }^{3}$

${ }^{1}$ Department of Mechanical Engineering, Faculty of military Technology, University of denence in Brno. E-mail: milan.chalupa@unob.cz.

${ }^{2}$ MSC Software. E-mail: josef.veverka@mscsoftware.com.

${ }^{3}$ Institute of Solid Mechanics, Mechatronics and Biomechanics, Faculty of Mechanical Engineering, Brno University of Technology, E-mail:vlach.r@fme.vutbr.cz.

The article describes mathematical model and possible usage of results of dynamic loading simulation of the chassis of track vehicle. The computational model is designed for computational simulating system MSC.ADAMS.AVT. Possibilities of research results usage are described in the article mainly. Results of simulation calculations were used for make-up of constructional parameters parts file of vehicle chassis and findings of influence their changes on changes of directional vehicle stability by running at first. Make - up of approximate relations for transaction of fast orientation calculations is second described possibility of results simulation calculations usage. The possibility of usage of results simulation to do verification of mathematical model is third possibility of usage results simulation calculations. The optimization of influence changes of several design value together is fourth possibility of usage of results simulation calculations that is described in this article.

Keywords: dynamic properties simulation, computation modeling

\section{Acknowledgement}

The article arose under effective supports of Experimental intention of Faculty of Military Technology of University of defence ev. No FVT 000401.

\section{References}

[1] BARTÁK, J., KRÓNEROVÁ, E., ŠEDIVÝ, P. (2004). Experimental certification of FEM calculation of sandwich materials on supporting steady head in car industry. In: Experimental stress analysis 2004. Plzeň: Škoda Výzkum, 2004. pp. 19-22. ISBN 80-239-2964-X.

[2] CHALUPA, M., VĚCHET, S., HOUFEK, L. (2010). Methodology of velocity and acceleration measurement of track link of track vehicle with usage of GPS. Publishing department of University of defence, Brno, CR, 2010, pp. 20, ISBN 978-80-7231-773-8.

[3] KOUCKÝ, MIROSLAV AND VALIŠ, DAVID, (2011). Suitable approach for non-traditional determination of system health and prognostics. In: Zeszyty naukowe, Styczen - Marzec, 2011, Vol. 1, No 159, pp. 123-134. ISSN 1731 - 8157 .

[4] SVOBODA, MARTIN, SOUKUP, JOSEF, (2013). Verification of Numeric Solution by Experiment for Examination Vertical Oscillation of a Mechanical System, Manufacturing technology, December 2013, vol. 13, № 4, pp. 559 - 563. ISSN $1213-2489$.

[5] SKOČIlAS, J., SKOČIlASOVÁ, B., SOUKUP, J. (2013). Determination of the rheological properties of thin plate under transient vibration. In: Latin American Journal of Solids and Structures. Vol. 10 (2013), No 1, pp. 187-193. Brazilian society for mechanics and engineering science. ISSN 1679-7817 (print), 1679-7825 (online).

[6] SVOBODA, M., SOUKUP, J. (2013). The Influence of Geometry, Manufacturing Asymmetry and Asymmetric Excitation on Vertical Vibration of a Mechanical System. In: Applied Mechanics and Materials, vol. 302 (2013), pp. 429-434. Trans Tech Publications, Switzerland.

[7] SVOBODA, M., SOUKUP, J. (2013). Dynamic Measurement of Four-Axle Railway Wagon, Manufacturing technology, December 2013, vol. 13, № 4, pp. 563 - 568. ISSN 1213 - 2489. 